http://dx.doi.org/10.12775/szhf.2015.019

Michą WRÓBLEWSKI

UNIWERSYTET GDAŃSKI, GDAŃSK

\title{
Kant okiem gnostyka
}

\section{Dlaczego tłumacz pism ezoterycznych zajmuje się Kantem?}

Jerzy Prokopiuk, tłumacząc różne teksty gnostyczne, wielokrotnie przyznawał, że na kształtowanie jego drogi życiowej największy wpływ miały teksty Carla Gustava Junga oraz Rudolfa Steinera. Polski thumacz przedstawia ich obu jako gnostyków chrystusowych ${ }^{1}$, twierdząc, że najważniejsza różnica pomiędzy antropozofią a psychologią analityczną dotyczy postrzegania filozofii $\mathrm{Kanta}^{2}$. O ile psychologia Junga określona została epistemo-

${ }^{1}$ „Wyróżniam następujące trzy rodzaje gnostycyzmu w zależności od źródła ich inspiracji: lucyferyczny, chrystusowy i arymaniczny. Pierwszy z nich dąży do wyzwolenia człowieka ze świata, w którym żyje, i reprezentowany jest przede wszystkim w gnostyctyzmach orientalnych i antycznych. Drugi - zrodzony z doświadczeń duchowych (inicjacyjnych św. Jana i św. Marii Magdaleny, podjęty przez ezoteryczną naukę Maniego, kontynuowany w poszukiwaniach świętego Graala, odrodzony u schyłku średniowiecza przez Christiana Rozenkreutza i osiągający apogeum w XX wieku w antropozofii Rudolfa Steinera - w ziemi widzi „athanor” narodzin i zbawienia człowieka, jego przemiany w istotę anielską. Trzecie wreszcie - za pomocą materialistycznej nauki i techniki oraz zniewalających człowieka teorii i praktyk społeczno-ekonomicznych i kulturowych - dąży do jego dehumanizacji, do przetransformowania go w istotę zwierzęco-maszynową" - J. Prokopiuk, Gnoza i ja - raz jeszcze, [w:] J. Prokopiuk, Z. Rosińska, Mel vitae = miód życia. 75-lecie Jerzego Prokopiuka, Wyd. Akasha, Kraków, 2010, s. 76.

2 „Steiner był wielkim wtajemniczonym, największym w XX wieku, i stworzył światopogląd wszechogarniający. Jung natomiast był przede wszystkim psychologiem - wtajemniczonym o tyle, o ile może być wtajemniczony psycholog-kantysta. (W moim przekonaniu bowiem 
logicznie przez rozróżnienie na rzecz samą w sobie oraz fenomeny, czyli archetypy i symbole; o tyle antropozofia Steinera nie tylko chciała wykroczyć poza ograniczenia poznawcze kantyzmu, lecz także uczyniła z królewieckiego myśliciela de facto jej największego filozoficznego oponenta. Świadczy o tym, niepozbawione argumentów ad personam, wymownie zatytułowane pismo: Anty-Kant. Palinodia. Prokopiuk, odwołując się w nim do konwencji utworu satyrycznego, powtarza rozsiane po różnych tekstach argumenty na temat kantyzmu, a scalając je, poniekąd wzmacnia. Gnostyczna w swojej wymowie polemika z dziedzictwem Krytyki czystego rozumu, odwołuje się przede wszystkim do rozważań Steinera z filozoficznego okresu jego twórczości, którego owocem były: praca doktorska: Wahrheit und Wissenschaft (1892), a przede wszystkim Filozofia wolności (1894) ${ }^{3}$. Na czym zatem polega krytyka krytycznego Kanta z punktu widzenia antropozofii?

\section{Wadliwy podział sądów}

Kantowski program filozofii transcedentalnej sprowadza się do odpowiedzi na trzy pytania: „Co mogę wiedzieć?”, „Co powinienem czynić?”, „Czego mogę się spodziewać?”. Próba odpowiedzi na pierwsze z wymienionych pytań, doprowadziła Kanta do rozważań na temat warunków możliwości uprawianych nauk, czyli matematyki oraz przyrodoznawstwa, lecz także logiki, a przede wszystkim metafizyki. W matematyce oraz w naukach przyrodniczych widoczny był postęp, w przeciwieństwie do takich działów filozofii, jak logika oraz metafizyka. Zdaniem autora Krytyki czystego rozumu, logika - określana jako formalne prawidła wszelkiego myślenia, narodziła się doskonała, niczym uzbrojona Atena z głowy Zeusa. Jeśli zatem logika jest doskonała, a rzeczy doskonałych nie da się poprawić, to zatem logiki nie da się poprawić ze względu na jej doskonałość. Z kolei porównane przez

sam sobie rzucił pod nogi „kłodę” kantowskiego samoograniczenia poznawczego - co było zarówno aktem roztropności [przynajmniej stara się pozostać uczonym akademickim], jak i - może - aktem skromności w epoce ceniącej minimalizm poznawczy). Dlatego tam, gdzie Steiner w swej gnozie aktywnej wyruszył w świat Ducha, Jung pozostał - niby w bezpiecznej skorupie czy batyskafie - w granicach duszy ludzkiej, choć także w jej wymiarze zbiorowym. I właśnie dlatego jako gnostyk muszę wyżej postawić Steinera niż Junga” - J. Prokopiuk, Półwiecze z Jungiem, [w:] tenże, Mój Jung, Wyd. KOS, Katowice 2008, s. 384.

${ }^{3}$ Prokopiuk wyróżnia cztery etapy w twórczości Steinera: goethenistyczny, filozoficzny, różokrzyżowo-teozoficzny, antropozoiczny" - J. Prokopiuk, Od filozofii do antropozofii, [w:] tenże, Labirynty herezji, Wyd. MUZA SA, Warszawa 1999, s. 90-91. 
Kanta do bitewnego zgiełku, niekończące się spory metafizyczne, świadczyły o tym, że w metafizyce nie dokonuje się postęp. Aby wyjść z impasu, należało zastąpić jałowy spór, rzetelnym postępowaniem procesowym, którego jednym z elementów był kluczowy dla teorii poznania podział sądów.

Po pierwsze, sądy różnią się między sobą ze względu na stosunek do doświadczenia, dzieląc się na: ogólne, powszechne i konieczne sądy aprioryczne oraz przygodne sądy aposterioryczne. Po drugie, sądy różnią się między sobą ze względu na stosunek podmiotu do orzecznika; dlatego dzielimy je na: sądy analityczne, w których z analizy podmiotu dochodzimy do znaczenia orzecznika, a także sądy syntetyczne, gdzie orzecznik wychodzi poza to, co zawarte w pojęciu podmiotu. Na podstawie powyższego podziału Kant wyróżnia cztery rodzaje zdań: analityczne $a$ priori, syntetyczne a prio$r i$, analityczne a posteriori oraz syntetyczne a posteriori. Sądy analityczne a posteriori zostały wymienione jedynie pro forma, gdyż są niespotykane. Sądy analityczne a priori są pewne i powszechne, ale nie wnoszą nic nowego do wiedzy o świecie, tak jak to się dzieje w logice. Sądy syntetyczne a posteriori wnoszą do wiedzy o świecie, ale nie są ani pewne, ani powszechne, czyli mówiąc językiem klasycznej filozofii, są mniemaniami (doksa). Natomiast sądy syntetyczne a priori powiększają naszą wiedzę o świecie w sposób pewny i konieczny, tak jak to się dzieje w matematyce oraz naukach przyrodniczych.

Co na to Prokopiuk? Zdaniem polskiego gnostyka wszystkie sądy wywodzą się z doświadczenia. Doświadczenie wyprzedza wszelkie pojęcia, tak samo jak obserwacja poprzedza wszelkie myślenie. Zdaniem Prokopiuka:

Sądy aprioryczne [...] Wynikają zatem albo z wiary w czyjeś doświadczenie, albo są czystą spekulacją opartą na tak zwanym „widzimisię”. (Jeżeli zaś biorą się z samych pojęć to: 1. odwołują się do doświadczeń - zewnętrznych lub wewnętrznych, z których wyrosły te pojęcia, albo 2 . do doświadczenia tych pojęćt.

Dla Prokopiuka sądy aprioryczne opierają się w gruncie rzeczy na doświadczeniu psychicznym lub duchowym, czyli jednak są aposterioryczne; o ile rzecz jasna powyższe rozróżnienie, w świetle wyżej zarysowanej interpretacji, posiada jakąkolwiek rację bytu.

Prokopiuk nie zgadza się również z podziałem sądów na analityczne i syntetyczne. Jego zdaniem wszystkie sądy są syntetyczne. W jaki sposób

\footnotetext{
${ }^{4}$ J. Prokopiuk, Anty-Kant. Palinodia, s. 40.
} 
zatem polski thumacz uzasadnia tezę o nieistnieniu sądów analitycznych? Jako przykład brane jest przez niego następujące zdanie: „Czerwień jest barwą”. Dla Kanta powyższe zdanie jest przykładem sądu analitycznego, gdyż stwierdzenie, że „czerwień jest barwą” nie mówi nic nowego na temat czerwieni. Prokopiuk zgadza się z Kantem, że powyższe zdanie nie mówi nic nowego o czerwieni, lecz dookreśla znaczenie nazwy „barwa”, wzbogacając konotację tej nazwy; co już jest syntezą, a nie jedynie analizą. Dzieje się tak dlatego, że czerwoność odsłania barwność, której ona sama nie wyraża. Innymi słowy, czerwoność jest przedstawiana, a barwność jedynie możliwa do pomyślenia ${ }^{5}$. Prawdą jest, że analizowany sąd nie wnosi niczego nowego do rozumienia czerwieni, ale pozwala lepiej rozumieć, czym jest barwność jako taka. Tak samo jak poznawanie różnych kultur pozwala lepiej rozumieć, czym jest kultura, chociaż nie zmienia ono pojęcia kultury jako takiej.

Czym zatem stanowisko Prokopiuka różni się od poglądu empiryków, którzy również kwestionowali kantowski podział sądów? Empirycy utożsamiają doświadczenie z doświadczeniem zmysłowym, redukując doświadczenie wewnętrzne do introspekcji, czyli odbitych przez pamięć i wyobraźnię wrażeń zmysłowych, tak zwanych impresji. Natomiast gnostycy mówią również o doświadczeniu pozazmysłowym bądź o doświadczeniu wewnętrznym ${ }^{6}$. Nie należy przy tym gnozy utożsamiać z mistyką, czego przykładem jest antropozofia Steinera, stroniąca zarówno od jednostronności przyrodoznawstwa, jak i mistyki ${ }^{7}$.

\footnotetext{
${ }^{5}$ Tamże, s. 41.

${ }^{6}$ „Gnoza (greckie gnosis) oznacza poznanie. W tym wypadku chodzi jednak o transracjonalne (a więc nieintelektualne) poznanie - Boga, istoty świata, siebie samego - przez wewnętrzne, bezpośrednie doświadczenie. Takie poznanie-doświadczenie otrzymuje człowiek w formie objawienia (spontanicznie, kiedy inicjatywa zdaje się wychodzić od Bóstwa lub jakiejś innej istoty duchowej) lub oświecenia czy wtajemniczenia (kiedy to człowiek zdaje się nam inicjować proces samoprzemiany - z reguły za pomocą trudnych i długotrwałych „treningów" ćwiczeniowo-medytacyjnych - zmierzających do uzyskania objawienia). Tak pojęta gnoza obejmowałaby także mistykę jako "gnozę niezamierzoną", intencją mistyka bowiem nie jest „poznanie” Boga, lecz utożsamienie się z nim lub upodobanie się do niego” - J. Prokopiuk, Gnoza, gnostycyzm, neognoza, [w:] tenże, Ścieżki wtajemniczenia. Gnosis aetarna, Dom Wydawniczy tchu, Warszawa 2000, s. 108.

${ }^{7}$ „We wstępie do swego wykładu Steiner podaje - jedno z kilku, jakie w ogóle podawał określenie antropozofii. Przytoczmy je dosłownie. «Przez antropozofię rozumiem naukowe badanie świata duchowego, które przenika jednostronność zarówno czystego przyrodoznawstwa, jak i zwykłej mistyki, i które - zanim podejmie próbę wniknięcia w świat ponadzmysłowy - w poznającej duszy rozwija najpierw nieznane jeszcze zwykłej świadomości i zwykłej
} 


\section{Bezsilne konsekwencje}

Wydaję się, że filozoficzny projekt Kanta jest próbą przekształcenia metafizyki w naukę, aby wyzwolić się od niekończących się sporów, prowadzących do obojętności, wątpliwości i sceptycyzmu. Do tego celu należałoby wymyślić metodę, której zalążkiem miała być krytyka. Co na to Prokopiuk? Polski gnostyk przede wszystkim wątpi w naukę jako najlepszy wzór do naśladowania dla filozofów, o czym świadczą następujące słowa:

Prawdy matematyki i (przyrodoznawstwa?) - pewne i powszechnie obowiązujące? Przecież się zmieniają i rozwijają! [...] Tyle co do „pewności” tych prawd. A ich powszechne obowiązywanie? W znanym na świecie - materialnym. (Inaczej w światach subtelnych czy w innych kosmosach.) $[\ldots]^{8}$.

Zacytowana wypowiedź sprawia raczej wrażenie drwiny ze scjentyzmu niźli krytycznego odniesienia do pism Kanta, który jak wiadomo, nie miał najlepszego zdania o antycypujących pozytywizm, tak zwanych indyferentystach.

Według Prokopiuka myśliciel z Królewca zupełnie niepotrzebnie traktuje naukę jako niedościgniony ideał, dostrzegając w powszechności i konieczności sądów dogmatyzm, prowadzący do unifikującego jednostkowe doświadczenie totalitaryzmu; upodabniającego naukę i metafizykę do znienawidzonych przez rodzimego heretyka instytucji kościelnych. Według niego, prawda wyrażona w symbolu jest pluralistyczna. Jego zdaniem:

Prawda filozoficzna nie może być i nie powinna być «naukowa» w swym dążeniu do Prawdy Absolutu nie musi być ani pewna, ani powszechnie obowiązująca. Każdy człowiek ma prawo do swej własnej prawdy, jako promienia Prawdy Absolutu?.

Wydaje się, że owa asymptotyczna koncepcja prawdy, nie podważa istnienia prawdy jako takiej, czy też możliwości zbliżania się do niej, lecz raczej przestrzega przed uzurpatorami, czyli tak zwanymi ludźmi religijnymi

nauce siły, jakie wniknięcie takie umożliwiają»" - J. Prokopiuk, Od filozofii do antropozofii, s. 92.

8 Tamże, s. 40.

9 Tamże, s. 39. 
w sensie dogmatyczno-instytucjonalnym. Zdaniem rodzimego ezoteryka ludzie religijni:

[...] wierzą w Prawdę Absolutną, choć z reguły znają tylko jedno jej objawienie, ale, co gorsza, sądzą także, że tym samym i ją znają - i reprezentują. [...] W ten sposób za Prawdę Absolutną uważają własną prawdę względnąa ${ }^{10}$.

Jednym z wniosków płynących z Krytyki czystego rozumu jest agnostycyzm poznawczy. Skoro metafizyka nie prowadzi do sądów pewnych i koniecznych, a także nie rozwija się, tak jak każda inna nauka, to powstaje pytanie, dlaczego tak się dzieje. Odpowiedź Kanta brzmi następująco: metafizyka stara się uporać z zagadnieniami, których rozwiązanie przekracza możliwości poznawcze ludzkiego rozumu. Trzy zagadnienia, określane mianem antynomii czystego rozumu (skończoność i nieskończoność kosmosu, śmiertelność i nieśmiertelność duszy, istnienie i nieistnienie Boga) są nierozstrzygnięte, ponieważ są nierozstrzygalne. Dlatego myśliciel z Królewca uchyla się od jednoznacznych odpowiedzi na wyżej wymienione kwestie, dochodząc do wniosku, że najrozsądniejszym sposobem korzystania z czystego rozumu jest jego samoograniczenie, czyli ograniczenie zakresu wszelkiej możliwej ludzkiej wiedzy do wiedzy o zjawiskach, a nie o rzeczy samej w sobie. Tak rozumiany agnostycyzm zostaje porównany przez autora palinodii do samookaleczenia. Warto przy tym zauważyć, że dość podobnie Prokopiuk określił lenistwo, które jest jednym z siedmiu grzechów (wad) głównych ${ }^{11}$. Należy przy tym dodać, że, według rodzimego gnostyka:

[...] grecki termin na określenie grzechu to hamartia $=$ „nietrafienie $\mathrm{w}$ cel”. Takie rozumienie grzechu ukazuje nam nową perspektywę. Grzesząc zbaczamy na manowce (w lewo bądź w prawo do celu) lub/i dopuszczamy się w czymś przesady (za „wysoko") albo niedociągnięcia (za „nisko") ${ }^{12}$.

Agnostycyzm zostaje określony jako myśl słaba, pozbawiona współpracy woli. Powiązana z grzechem bezsilność agnostycyzmu wskazuje również na

\footnotetext{
10 Tamże, s. 43.

${ }^{11}$ „[...] winę Byka - gnuśność i samouwięzienie - przekształcić w energię wyzwolenia («ziemię» zrównoważyć "powietrzem»)"- J. Prokopiuk, Jungowska transformacja „cienia” i jej gnostyczne procedury i późniejsze parabole, [w:] J. Prokopiuk, Z. Rosińska, Mel vitae = miód życia. 75-lecie Jerzego Prokopiuka, s. 252.

12 Tamże, s. 248.
} 
słabość natury moralnej tego typu wniosków natury poznawczej. Prokopiuk thumaczy ową bezsilność samoograniczenia faktem, iż w tym wypadku motywacja zewnętrzna poznania, czyli ciekawość, została powściągnięta przez bezinteresowną wolę prawdy ${ }^{13}$.

Przejawem wskazanego zablokowania samego siebie jest deklarowany pesymizm poznawczy, którego konsekwencją jest postulowany w rozumie praktycznym fideizm. Prokopiuk nie bez sarkazmu reaguje na często przytaczane słowa królewieckiego myśliciela: „Kant: „Musiałem obalić wiedzę, by zrobić miejsce dla wiary". (Oto przyznanie się do swej najgłębszej intencji! I to mówi filozof i uczony?!)"14. Sarkastyczna uwaga wskazuje poniekąd na brak konsekwencji w rozumowaniu Prokopiuka. Albowiem, gnostyk $\mathrm{z}$ jednej strony oskarża Kanta o to, że jest aż nazbyt uczony, dyskredytując wszelką wiedzę, która nie opiera się na sądach powszechnych i koniecznych, z drugiej zaś strony, wytyka mu, iż rezygnuje on ze swej uczoności, opowiadając się w ostatecznym rozrachunku za wiarą. Zdaniem polskiego gnostyka, taka postawa stoi w opozycji do szeregu biblijnych napomnień, nawołujących człowieka do prób poznania Boga o własnych siłach, bez daremnego odwoływania się do bożej łaski. Prokopiuk ocenia zatem filozofię kantowską jako myśl słabą, czy wręcz bezsilną, stanowiącą pogłębienie rozziewu pomiędzy wiedzą i wiarą, które narastało w kulturze europejskiej od późnego średniowiecza aż po czasy współczesne, ze szczególnym uwzględnieniem, przesiąkniętego materializmem, XIX wieku.

\section{W poszukiwaniu źródeł błędnych przesłanek}

Prokopiuk stoi przed następującymi pytaniami: Czym zatem wytłumaczyć, że Kant, poznając ograniczenia ludzkiego poznania, nie dążył do ich przezwyciężenia? Dlaczego wbrew deklaracjom autor Krytyki czystego rozumu nie dokonał rewolucji w myśleniu, lecz jedynie doszedł do wniosku, że podmiot dostosowuje przedmioty do siebie w akcie poznania ${ }^{15}$ ? Polski

\footnotetext{
13 „Kant kierował się obu motywacjami, ale motywację wewnętrzną wykorzystał jedynie do sparaliżowania swego dążenia poznawczego, jego autokastracji, mocnego samoograniczenia go, pokazania, czego rzekomo nie może" - J. Prokopiuk, Anty-Kant. Palinodia, s. 36-37.

${ }_{14}$ Tamże, s. 53.

${ }^{15}$ „Możliwe są trzy formy relacji między podmiotem a przedmiotami: 1) podmiot dostosowuje się do przedmiotów, 2) podmiot dostosowuje przedmioty do siebie, 3) podmiot i przedmiot harmonizują się, to znaczy dostosowują się do siebie nawzajem (Metafizyka, Kant, Steiner)". Tamże, s. 38.
} 
gnostyk, starając się odpowiedzieć na postawione pytanie, odwołuje się zarówno do różnego rodzaju argumentów, które bazują na przekonaniu, iż filozof z Królewca nie dokonał kopernikańskiej rewolucji w myśleniu, lecz co najwyżej stworzył przeciwwagę dla sceptycyzmu i dogmatyzmu, słusznie wskazując na ograniczenia dotychczasowego sposobu uprawiania filozofii. Jednak poza samoograniczeniem niewiele więcej zrobił, twierdząc, że nie sposób dotrzeć do rzeczy samej w sobie, lecz jedynie poznawać samego sie$\mathrm{bie}^{16}$.

Należy przy tym pamiętać, że dla Prokopiuka kantowski agnostycyzm jest kryptomaterializem. Czym jest ów materializm? Wythumaczenie tego terminu znajduje się w jednym z pism Steinera:

Widać stąd, że pojęcie materializmu trzeba rozumieć szerzej, niż to się zazwyczaj czyni. Kogo myślenie zmusza do przekonania, że w jego duszy nie może ożyć nic z realnej „rzeczy samej w sobie”, ponieważ jej materia nie może przenieść się do niej, ten jest materialistą, jeśli nawet sądzi, że jest idealistą, ponieważ uznaje istnienie duszy. A właśnie Kanta do jego wyobrażeń doprowadził jego ukryty materializm ${ }^{17}$.

Poza tym także historycy filozofii zwracają uwagę na to, iż dzieło niemieckiego myśliciela, nawiązuje do Locke'a i Hume'a nie tylko w koncep$\mathrm{cji}^{18}$, redukując doświadczenie do danych zmysłowych, w przeciwieństwie chociażby do scholastyków, którzy traktowali Objawienie jako coś, co należy przyjmować jako dane, czy też gnostyków, przekonanych o istnieniu rzeczywistości ponadzmysłowej.

Kantowska praca krytyczna doprowadziła do swoistego paraliżu poznawczego, który został skomentowany przez polskiego ezoteryka w niezbyt wybredny sposób. Prokopiuk nazywa królewieckiego filozofa onanistą, tłumacząc, że poznanie pozbawione możliwości dotarcia do rzeczy samej w sobie jest abstrakcyjną formułą, określającą niemożność dotarcia do natury rzeczywistości, której uosobieniem jest kobiece łono. Zdaniem gnostyka:

\footnotetext{
16 „Przedmioty dostosować do człowieka? To znaczy nigdy nie poznać przedmiotów, a jedynie poznawać człowieka. (Poznanie tego, co ludzkie - w rzeczach?)”. Tamże, s. 38.

${ }^{17}$ Cyt. za J. Prokopiuk, Od filozofii do antropozfii, s. 105.

${ }^{18}$ „Zaczątki krytyki znajdujemy u Locke’a, następnie zaś u Hume’a w pytaniu: do czego w ogóle zdolna jest ludzka władza poznawcza” - O. Höffe, Kant, przeł. Andrzej M. Kaniowski, Wyd. PWN, Warszawa 1994, s. 51.
} 
W przypadku Kanta wpłynęła na jego agnostycyzm zarówno jego struktura psychofizyczna, jak i jego protestanckie korzenie: lęk przed światem czy naturą uosobioną przez kobietę i lęk przed Bogiem: samoobronny skrajny egocentryzm. (Autokastracja cielesna i duchowa) ${ }^{19}$.

Skojarzenie poznania z kobiecym łonem wydobyte jest z Biblii, gdzie słowo oznaczające «poznanie» występuje w dwóch znaczeniach: seksualnym i gnostycznym ${ }^{20}$.

Polski tłumacz zwraca również uwagę, że próba budowania metafizyki na podstawie sądów pewnych, koniecznych i powszechnie obowiązujących, upodobnia ją nie tylko do matematyki, lecz również do dogmatów religijnych. Kantowskie myślenie o świecie pod wieloma względami uwikłane jest we wrogi mistyce protestantyzm, traktujący poznanie Boga, czyli gnozę jako uzurpację i bluźnierstwo. W luteranizmie jedynie poprzez akt wiary człowiek może liczyć na boską inicjatywę w postaci objawienia. Kant, wskazując na samoograniczenie jako drogę filozoficznego myślenia, nawiązał do antyintelektualnej postawy Marcina Lutra, który nazwał rozum ,ślepym głuchym błaznem"21.

Prokopiuk jako krytyk instytucjonalizacji chrześcijaństwa krytycznie wypowiada się o protestantyzmie, który w jego opinii jest kryptojudaizmem. Dzieje się tak dlatego, że protestantyzm z podejrzliwością traktuje osobisty kontakt człowieka z Bogiem, praktycznie zapoznając przyjście na świat Chrystusa. Ezoteryczny chrześcijanin przypomina, że niemiecki filozof zdaje się nie pamiętać o jednej z podstawowych prawd wyznawanej przez siebie wiary:

Skoro Bóg zamieszkał w człowieku, to znaczy - mówiąc językiem Kanta - że rzecz sama w sobie nie jest oddzielona od zjawisk; przeciwnie - żyje w nich i stopniowo je przemienia, to znaczy zbawia. Dlatego jest dostępna im poprzez nie same, jeśli - we współpracy z nią - będą się przemieniać zarówno poznawczo, jak moralnie - a także ontycznie ${ }^{22}$.

\footnotetext{
${ }^{19}$ J. Prokopiuk, Anty-Kant. Palinodia, s. 36.

${ }^{20}$ „W Biblii, jak wiadomo, słowo «poznanie» ma dwa znaczenia: seksualne i gnostyczne. Kiedy czytam, że Abraham poznał Sarę, znaczy to zarówno, że odbył z nią stosunek seksualny, jak i to, że poznał ją w sensie ludzkim, czy zgoła towarzyskim” - J. Prokopiuk, Anty-Kant. Palinodia, s. 35.

${ }^{21}$ J. Prokopiuk, Od filozofii do antropozofii, s. 98.

22 J. Prokopiuk, Anty-Kant. Palinodia, s. 55.
} 
Dla Prokopiuka religijne wychowanie oraz specyficzna osobowość myśliciela z Królewca, stanowiły kulturowe tło, które wpłynęło na ,autokastracyjny" charakter kantyzmu, pogłębiający przepaść między wiedzą a wiarą.

\section{Filozofia wolności a epistemologia samoograniczenia}

Czy zatem filozof z Królewca słusznie porównywał siebie do Kopernika? Prokopiuk nie uważa Kanta za wielkiego odkrywcę, aczkolwiek docenia on pewne zasługi krytyki, wymierzonej przeciwko sceptycyzmowi i dogmatyzmowi. Odwrócenie jednak relacji pomiędzy podmiotem i przedmiotem, jakie widoczne jest w filozofii transcedentalnej, nie prowadzi do poznania prawdy, lecz do poznania człowieka (poznania tego, co ludzkie w rzeczach). Dlatego określenie filozofii kantowskiej jako „przewrotu kopernikańskiego” jest w gruncie rzeczy fałszywe. Prokopiuk zatem uważa, że Kant słusznie dostrzegł problem, ale nie znalazł dobrego rozwiązania. Jego zdaniem właściwą drogą wyjścia z bezdroży myśli filozoficznej jest antropozofia Steinera, dążąca nie tylko do określenia tego, co ludzkie w poznaniu, lecz także polegająca na przekształceniu instrumentarium poznawczego, jakim dysponuje człowiek: nie tylko percepcji, lecz również myśli. Temu celowi służą różne techniki antropozoficzne, dążące do zharmonizowania ze sobą podmiotu i przedmiotu poznania, a więc przekształcenia podmiotu, a nie tylko poszerzenia jego możliwości poznawczych przez takie instrumenty, jak teleskopy czy mikroskopy. Asekurancki Kant stroni od wyżej zarysowanego ryzyka, uprawiając epistemologię samoograniczenia, porównując się poniekąd do policjanta. Natomiast Prokopiuk, idąc śladem Steinera, gotowy jest porzucić powściągliwość poznawczą po to, by mieć możność poznania świata duchowego. Polski gnostyk, który obficie czerpie z pism założyciela antropozofii, wydaje się raczej czytelnikiem Filozofii wolności i Drogi do wtajemniczenia niż Krytyki czystego rozumu, co sprawia, że nie mamy tutaj do czynienia z krytycznym namysłem nad kantyzmem, lecz niesystematycznym zbiorem uwag, podważającym główne założenia filozofii krytycznej z punktu widzenia wiedzy o charakterze transracjonalnym, jakim jest gnoza. Brak systematyczności uzupełniony jest przez wyjątkowy, jak na gnostyka ton polemiki, godzącego w osobę samego filozofa, przedstawianego $\mathrm{w}$ palinodii wręcz karykaturalnie. Albowiem jeden z najważniejszych myślicieli w dziejach filozofii, starający się przezwyciężać ograniczenia poznawcze empiryzmu, racjonalizmu i sceptycyzmu został przedstawiony jako jednostka aż nazbyt bojaźliwa, a przy okazji na swój specyficzny sposób leniwa. Bojaźliwość fi- 
lozofa uniemożliwiła mu zarówno kosztowanie rozkoszy poznawczych, jak i tych najbardziej przyziemnych.

\section{Bibliografia}

Höffe O., Kant, przeł. Andrzej M. Kaniowski, Wyd. PWN, Warszawa 1994.

Prokopiuk J., Anty-Kant. Palinodia, [w:] J. Prokopiuk, Z. Rosińska, Mel vitae = miód życia. 75-lecie Jerzego Prokopiuka, Wyd. Akasha, Kraków, 2010.

Prokopiuk J., Gnoza, gnostycyzm, neognoza, [w:] J. Prokopiuk, Ścieżki wtajemniczenia. Gnosis aetarna, Dom Wydawniczy tchu, Warszawa 2000.

Prokopiuk J., Jungowska transformacja „,ienia” i jej gnostyczne procedury i późniejsze parabole, [w:] J. Prokopiuk, Z. Rosińska, Mel vitae = miód życia. 75-lecie Jerzego Prokopiuka, Wyd. Akasha, Kraków 2010.

Prokopiuk J., Pólwiecze z Jungiem, [w:] J. Prokopiuk, Mój Jung, Wyd. KOS, Katowice 2008.

Prokopiuk J., Od filozofii do antropozofii, [w:] J. Prokopiuk, Labirynty herezji, Wyd. MUZA SA, Warszawa 1998.

\section{Abstract \\ Kant in the Eyes of a Gnostic}

Anthroposophy seeks to overcome the limitations of cognitive philosophy of Kant. George Prokopiuk has admitted to a fascination with anthroposophy of Rudolf Steiner. Polish Gnostic, questioning the Kantian division of the courts (analytic / synthetic, a priori / a posteriori), saw in them agnostic powerlessness. In his opinion, the reason for the weakness of Kant was a materialist understanding of the experience, Protestantism and personal life of the philosopher.

Key words: anthroposophy, analytic, synthetic, a priori, a posteriori, agnosticism, experience, protestantism 